\title{
The Question of Being: Foremost Hermeneutic Pre-condition for Interpreting Heidegger
}

\author{
Parvis Emad \\ University of Wisconsin-La Crosse. Department of Philosophy \\ La Crosse, WI 54601 USA
}

\begin{abstract}
Seventy-five years after the publication of $S u Z$, this work still not interpreted in the light of the question of being - few exceptions notwithstanding. To commemorate the seventy-fifth anniversary of the publication of $S u Z$, it is fitting to take up this question, and to attend to its structure and hermeneutic ramifications. Returning to this question we come upon and experience a phenomenon which Heidegger calls «retro- or forward relatedness of being» and which constitutes the foremost hermeneutic pre-condition for gaining access to his entire thought. It is the purpose of this paper to indicate that this relatedness sustains Heidegger's trascendental-horizonal as well as his being-historical thinking.
\end{abstract}

Key words: question of being, existence, hermeneutic, Being and Time.

Resumen. La cuestión del ser: condición hermenéutica previa indispensable para la interpretación de Heidegger

Pasados setenta y cinco años de la publicación de Ser y tiempo, esta obra todavía no se ha interpretado desde la perspectiva de la cuestión del ser, al margen de algunas excepciones. Para conmemorar el setenta y cinco aniversario de la publicación de Ser y tiempo, abordaremos este tema y nos ocuparemos de su estructura y de sus ramificaciones hermenéuticas. Volviendo a la cuestión que centra nuestro interés, fijaremos la atención en la experiencia de un fenómeno que Heidegger denomina «retro-relación» o "proto-relación» del ser que constituye la pre-condición hermenéutica fundamental a la hora de acceder a la totalidad de su pensamiento. Este artículo se propone indicar que esta relación sustenta tanto el pensamiento horizontal-trascendental de Heidegger como su pensamiento acerca de la historia del ser.

Palabras clave: cuestión del ser, existencia, hermenéutica, Ser y tiempo.

\section{Table of contents}

I. Structure of the Question of Being

III. The Yields of the Question of Being

II. Existence, the Site' of Retroor Forward Relatedness of Being 
[...] the keen boldness of the question of being, [...] always shatters machination of beings and its denial of be-ing and must persevere in the unease and cleavage of a breakage so that thinking of be-ing never dares to come to rest in a "work.»"

On the occasion of the seventy fifth anniversary of the publication of Sein und Zeit it is fitting to return to the question of being (die Seinsfrage) and to discuss its structure and hermeneutic import, since this question constitutes the foremost hermeneutic pre-condition for interpreting Heidegger's thought. We shall take up the question of being because seventy five years after the publication of Sein und Zeit this work is still not interpreted and appropriated in the light of this question, few exceptions notwithstanding. Considering the current situation surrounding Sein und Zeit, one cannot fail to notice that for the most part the guiding significance of the question of being, and its hermeneutic import are neglected. It is our considered opinion that the failure to properly attend to the question of being is ultimately responsible for the many misinterpretations that presently beset Heidegger's thought.

It is well known that Heidegger repeatedly referred to the question of being as his one and only question and viewed it as pivotal to his entire thought. Whether it was in Being and Time that he said "the question of the meaning of being should be asked», ${ }^{2}$ or in Contributions to Philosophy that he inquired "But how does be-ing sway?» ${ }^{3}$ in both works he stressed the guiding significance of this question for understanding the transcendental-horizonal or being-historical pathways of his thinking. However, when we look closely at recent works that deal with Heidegger, especially those devoted to Sein und Zeit, we find that for the most part they go wrong because they either misconstrue the question of being, or ignore it altogether. Characterizing the question of being as an «ethereal question», ${ }_{4}^{4}$ misconstruing being (Sein) by conflating funda-

1. M. Heidegger (1997), Besinnung (Frankfurt am Main: V. Klostermann), p. 51. All references in the text to Heidegger's Gesamtausgabe use abbreviation GA followed by volume and page number. For detailed bibliographical information regarding this edition, see Heidegger Studies (Berlin: Duncker \& Humblodt, 2001), p. $187 \mathrm{ff}$. All translations from volumes of Heidegger's Gesamtausgabe are by the author. Bold type inside quotation marks and in the body of the text are used for emphasis.

2. GA $2 / 6$.

3. M. Heidegger, Contributions to Philosophy (From Enowning), translated by Parvis Emad and Kenneth Maly (Bloomington: University of Indiana, 1999), p. 5, hereafter referred to as Contributions followed by page number.

4. T. KISIEL, The Genesis of Heidegger's "Being and Time» (Berkeley: University of California, 1993), p. 364. For a thoroughgoing critique of this work, see Tomy S. KALARIPARAMBIL, "Towards Sketching the "Genesis" of Being and Time» in Heidegger Studies (Berlin: Duncker \& Humboldt), 16/ 2000, p. 189-220. 
mental ontology and sociology, ${ }^{5}$ obfuscating the question of being with «an alternative ontological model», ${ }^{6}$ and the claim that Heidegger "privileges questioning» ${ }^{7}$ — to mention only a few — are among the most blatant errors that shape recent interpretations of Heidegger's thought. A glance at the recent literature shows that most interpreters do not address the structure of the question of being, and do not realize that Heidegger analyzes this question, because he wants to show that being reverberates in this question. The current misinterpretations are clear indications that commentators have not yet grasped the question of being as the foremost hermeneutic pre-condition for interpreting Heidegger. Thus it should be clear that, we must return to this question.

However indisputable the importance of the question of being is for appropriately entering into, and interpreting Heidegger's thought in general and Sein und Zeit in particular, it is not ipso facto clear what this returning is all about. To return to this question means gaining access to, and experiencing a phenomenon, which Heidegger in his analysis of the structure of the question of being calls «retro- or forward relatedness» (Rück-oder Vorbezogenheit) ${ }^{8}$ of being. Question of being is the foremost hermeneutic pre-condition for interpreting Heidegger because being is retro- or forward related to, and reverberates in this question. Thus to see the guiding significance of this relatedness and reverberation, we have to return to the analysis of the structure of the question of being.

5. H. Dreyfus (1991), Being-in-the-World, Cambridge (MA): MIT Press, p. 145. In its entirety this work is guided by the mistaken assumption that

Society is the ontological source of the familiarity and readiness that makes the ontical discovery of entities, of others, and even of myself possible (p. 145).

This shows how little Dreyfus understands Heidegger's concept of the world. Although world in Heidegger is not the «source» of anything, if we insist in calling it a «source», we should keep in mind that it is not society but world that is the ontological «source» of the discovery of «entities». The reason is simple: like Umwelt, society too is innerworldly. Dreyfus misinterprets the world because he fails to properly grasp the question of being. For more on this failure, see note 14 below.

6. J. MCCumber (1999), Metaphysics and Opression: Heidegger's Challenge to Western Philosophy (Bloomington: University of Indiana, p. 208). In this book, McCumber fails to approach Being and Time through an analysis of the question of being. Instead he imposes upon this work the preconceived thesis according to which Heidegger in Being and Time puts forth

[...] an alternative ontological model, one on which at least some beings are generated and shaped not by form but by $[\ldots]$ an active, shaping gap (p. 14).

McCumber assumes that this gap, is detectable in the ecstases of temporality. He thus fails to see that this temporality is a onefold. For a thoroughgoing critique of this unfounded thesis, see Thomas KaLARY, "Hermeneutic Pre-conditions for Interpreting Heidegger: A look at Recent Literature» (Part One), Heidegger Studies, 18/ 2002, p. 159-180.

7. J. DERRIDA (1987), De l'esprit: Heidegger et la question, Paris: PUF, passim.

8. GA 2/ 11 . 


\section{Structure of the Question of Being}

Fundamental ontology begins with depiction of structure of the "fundamental question" ${ }^{9}$ of being, i.e., structure of a question, which although unasked and unheeded, has been the spur behind philosophical thinking all along. It is, therefore, fair to say that this depiction represents a watershed in Western philosophy's preoccupation with being. However, in addition to its importance for the history of Western philosophy, depiction of this structure also holds the key for understanding that Heidegger's thinking of being differentiates itself from the thinking of being, which as metaphysics, has dominated and shaped Western philosophy. Equally important is that by analyzing the structure of the question of being, Heidegger puts forth being's retro- or forward relatedness to this question, and thus provides a unique access to the fundamental-ontological as well as being-historical pathways of his thinking.

It is important to note that Heidegger's demonstration of structure of the question of being comes as a formal indication (formale Anzeige). It is also important to note that being's retro- or forward relatedness - once experienced - removes the question of being out of a tension which in formal indication of this question prevails between the phase of indication and the phase of fulfillment. In the moment of enactment of the question of being this tension no longer holds: in that moment we come to experience the resonance of being, i.e., being's retro- or forward relatedness to questioning.

Specifically inquiring into the meaning of being, question of being is structured, first by «that which this question asks about» (das Gefragte), secondly by «that which this question interrogates» (das Befragte) and thirdly by «that which this question ascertains» (das Erfragte). ${ }^{10}$ By outlining this structure, Heidegger shows that retro- or forward relatedness of being is the moment we have to fully grasp if we want to enter into the fundamental-ontological as well as being-historical pathways of his thinking. In order to see this relatedness clearly, we shall begin by attending to the first and third structural items in the question of being.

The analysis of the structure of the question of being begins with the insight according to which every question is guided in advance by what the question seeks, which in the case of the question of being is the meaning of being. But we could not seek this meaning if it were utterly unknown to us, which means that we must have an access to, and be familiar with being and its meaning. In raising this question we do not know what being means but when

[...] we ask, «what is being?» we are situated within an understanding of the «is» without being able to conceptually establish what the «is» conveys. ${ }^{11}$

It is in view of situatedness in, and familiarity with being and its meaning, that in formal indicative respect Heidegger identifies being as what is asked 
about in this question. The significance of this identification guides and reaches into Heidegger's hermeneutic efforts which distinguish his fundamental-ontological and being-historical thinking from traditional preoccupation with being. However, an important consequence of this identification is the realization that being and its meaning require a demonstration and an exposition entirely their own. As Heidegger puts it

[...] being, what is asked about, demands its own kind of exposition which is essentially different from the discovery of beings. ${ }^{12}$

The same is true of what this question ascertains, namely the meaning of being. This meaning too requires its own conceptuality, which again distinguishes itself essentially from the concepts in which beings obtain their determination according to meaning. ${ }^{13}$

Exposition and conceptualization clearly involve language. Thus when Heidegger stresses the need for an exposition and conceptualization that are peculiar to being and its meaning, he alludes to the language of being. (This shows that as early as the analysis of structure of question of being, Heidegger «speaks» the language of being. Because this language is not the familiar language, any attempt to «translate» this language into a «more familiar» language amounts to abandoning Heidegger's thought altogether.)

What can be said about being — being we are already familiar with and to which we have an access via situatedness in, and understanding of being? When we inquire about being we already know that being is

[...] that which determines a being as a being, that is, that in view of which (woraufhin) a being, however it may be discussed, is always already understood. ${ }^{14}$

12. GA $2 / 8$.

13. GA 2/ 8-9.

14. GA 2/ 8. We consider this characterization of being pivotal for interpreting Being and Time, and the failure to properly grasp this characterization responsible for Dreyfus's complete misinterpretation of this work. With the first step that Dreyfus takes to enter into the structure of the question of being, he shows how little he understands this structure. He equates Heidegger's characterization of being (namely «that which determines a being as a being, that in view of which (woraufhin) a being... is always already understood)", with a traditional

[...] formula that is sufficiently ambiguous to cover some sort of supreme Being, a constituting activity like that of a transcendental ego, and the intelligibility revealed by our background practices (p. 12).

Thus he fails to see that being is that in view of which (woraufhin) beings are understood. This failure is also evident in Dreyfus's attempt to bring into English the central word woraufhin which he translates as "on the basis of which». Being, or what is asked about, is not "a basis» but "that in view of which" (woraufhin) beings are understood. What is at stake here is «viewing», i.e., a phenomenological «act» that has nothing in common with "basing» something on something else. By failing to grasp being, Dreyfus paves the way for misinterpreting Division I and Division II of Being and Time: he misconstrues Division I by taking it as the place in which Heidegger espouses pragmatism a la W. James and J. Dewy, (cf. op. cit., p. 6) and he misinterprets Division II by taking it as the place in which Heidegger advocates existentialism (cf., op. cit., p. XIII). 
Because we are already familiar with, and have an access to being, we can say that being is what determines a being as a being and is that in view of which a being is understood. This means that we already know that being is different from beings, which is to says that we are already familiar with, and have an access to the difference between being and a being. How else would we determine a being as a being unless we are guided by being as that in view of which a being is always already understood? When Heidegger says that "the being of a being "is" itself not a being»" 15 he offers the first formal indicative formulation of the ontological difference.

This means that when in formal indicative respect Heidegger points out that what is asked about in the question of being is being, and what is ascertained in this question is the meaning of being, he demonstrates that his thinking is guided in advance by what transpires (is not assumed) as ontological difference. This makes clear that the entirety of the analysis of structure of question of being is carried out under the auspices of the ontological difference - an analysis that extends to the second structural item (that which is interrogated).

Heidegger proceeds to formally indicate what is interrogated in the question of being by taking another look at (or re-viewing) what is asked about in the question of being. He concludes that since what is asked about, namely being, is always already being of a being, what is interrogated must be a being:

Insofar as being makes up what is asked about, and being means being of a being, what is interrogated in the question of being proves to be a being itself. The latter is, so to speak, what is questioned with regard to its being. ${ }^{16}$

But how are we to find out which being is to be interrogated? Does this require that we run through and examine every conceivable class and kind of beings, or is it the case that the being to be interrogated shows itself undistorted as it is from within the fundamental question of being? Conceivably anything and everything is a being. Everything we talk about, everything we have in mind, everything toward which, one way or the other, we comport ourselves is a being. Given this omnipresence of beings, we have to say that in raising the question of being we are always confronted with modes and ways of being:

Being resides in thatness and whatness, in reality, extantness, constancy, validity, existence and in "there is». ${ }^{17}$

When we consider these modes and ways of being in which being means being of a being, we have to conclude above all that what has to be interro- 
gated is a being. Thereafter, we have to proceed with determining the proper access to this being.

On the way to determining the being which is to be interrogated and finding the right access to this being, Heidegger brings together — one might say hastily - the meaning of being, and the being which is to be interrogated (but is as yet not wholly identified) and asks:

In which being is the meaning of being to be discerned; with which being we have to begin in order to conclude with being? ${ }^{18}$

Heidegger is aware that this question is hastily formulated, because in a marginal note he points out that this question contains within itself two quite different questions. While the first question «In which being is the meaning of being to be discerned?» implies that this meaning is discernible in a being, the second question "With which being we have to begin in order to conclude with being?» implies that departing from a being leads directly to being and its meaning. These two questions do not clearly keep apart the meaning of being as such and the meaning of being of a being in whose being the meaning of being can be discerned. Heidegger criticizes this passage and thus opens the way for elucidating it. He says:

Here two different questions follow each other; misunderstandable, especially with regard to the role of Dasein. ${ }^{19}$

Indeed here two different questions follow each other insofar as «In which being is the meaning of being to be discerned?» is a question quite different from "with which being we have to begin in order to conclude with being?». Setting out from these questions in order to find out what is to be interrogated, and not differentiating the question "In which being is the meaning of being to be discerned?» from the question "With which being we have to begin in order to conclude with being?» amounts to succumbing to the misunderstanding that both questions ask about the same thing. ${ }^{20}$ These questions ren-

18. GA 2/ 9. Regarding this passage, cf., the pioneering work of F.-W. vON HERRMANn (1987), Hermeneutische Phänomenologie des Daseins: Eine Erläuterung von Sein und Zeit, vol. 1 (Frankfurt am Main: V. Klostermann), p. 59-65.

19. Ibid.

20. Had Dreyfus grasped the difference between these two questions, and had he realized that the meaning of the being to be interrogated in the question of being is not the same as the meaning of being, presumably he would have refrained from saying that "what is studied in Being and Time ultimately is not Dasein but Dasein's way of being” (op. cit., p.14). Since the meaning of the being of Dasein is not the same as the meaning of being, and because Dasein is a being in whose being the meaning of being as such can be discerned, it is wrong to limit Being and Time to a study of Dasein's way of being. For, given the difference between the meaning of the being to be interrogated and the meaning of being, what is studied in Being and Time can also be said to be the meaning of being. For this see GA 2, Division II, and GA 24, which Heidegger designates «The new elaboration of Division III of Part One of Being and Time». 
der misunderstandable the role of the being to be interrogated (Dasein) insofar as they may be taken to suggest that we can accomplish the exposition of what is asked about, i.e., being by departing from the being to be interrogated, and then identify the meaning of this being with the meaning of being as such, i.e., meaning of beings other than Dasein. However, considering the unfolding of fundamental ontology as a whole (which takes the entirety of Being and Time and The Basic Problems of Phenomenology) we have to say that the meaning of the being to be interrogated (Dasein), namely temporality (Zeitlichkeit) is not at all the same as the meaning of beings other than Dasein, i.e. Temporality (Temporalität). We discern the meaning of beings other than Dasein in the being to be interrogated without conflating the meaning of the being to be interrogated with the meaning of being.

Granted that we differentiate the meaning of being as such from the meaning of the being to be interrogated - which presupposes that we understand the ramifications of the two questions concerned with «in which being...?» and «with which being...?» — we should be in a position to formally indicate the being to be interrogated and determine the access to this being. Heidegger stresses the importance of this access when he says that «In view of that which is to be interrogated in the question of being, this question requires obtaining, and securing in advance the right access to a being». ${ }^{21}$ His concern with the right access to the being to be interrogated becomes more clear when he asks:

Is the point of departure arbitrary or has a certain being a preeminence (Vorrang) in working out the question of being? ${ }^{22}$

In order to formally indicate what is to be interrogated, we must have an access to a being that is a preeminent being. The preeminence of this being makes it an exemplary being and opens in advance the right access to this being. The formal indicative quest for what is to be interrogated reaches a decisive stage when we realize that the being to be interrogated is a preeminent and exemplary being. But with this realization we have not yet determined which being is the exemplary being. That is why Heidegger asks: «Which is this exemplary being and in what sense is this being a preeminent being?» ${ }^{23}$ No sooner does he raise this question that he recognizes the risk that comes along with this word «exemplary». That is why in a marginal note he explicitly critiques this word and says that it is "misunderstandable». ${ }^{24}$

In an effort to specifically identify the preeminent being, it is misunderstandable to call the being to be interrogated an exemplary being, because this word could be taken to mean a being which is an «example» and as such belongs

21. GA $2 / 9$.

22. Ibid. We translate Vorrang with preeminence in order to distinguish it from priority, i.e., from a word with strong ties to epistemology.

23. Ibid.

24. Ibid. 
to a class. The connection with a class is what makes the designation «exemplary» risky. As long as we are taken in by the notion of membership in a class, we fail to see the preeminence of this being in a proper light. For, this preeminence has nothing to do with membership in a class. The being to be interrogated is preeminent, not because it is an «example» of, and belongs to a class but because it is situated in an understanding of the "is». It is this situatedness that makes possible for this being to be the being wherein the meaning of being can be discerned, and it is this situatedness that accounts for the preeminence of, and the right access to this being. The only way to use the word exemplary appropriately is to use it against the background of situatedness in, and understanding of the «is». We can say then that the being to be interrogated is preeminent among beings because of its situatedness in the understanding of the «is». If the preeminence of this being is because of its situatedness in understanding of the «is», then this understanding is what provides an access to this being.

However, situatedness in understanding of the «is», i.e., understanding of being, and preeminence of the being to be interrogated, as well as the access to this being are manifest in certain comportments that are constitutive of this being. Heidegger enumerates these comportments when he says:

If we are to explicitly raise the question of being and to enact this question as completely transparent to itself, then, following elucidations we have given so far, elaboration of this question requires us to explicate the way we turn our gaze toward being, the way we understand and conceptually grasp meaning, prepare the possibility of the right choice of the exemplary being, and work out the genuine kind of access to this being. ${ }^{25}$

By enumerating these comportments and by naming each specifically, Heidegger indicates that without exception these comportments are comportments of a being that is situated in understanding of being. Accordingly, turning the gaze toward being no less than other comportments (grasping meaning, preparing the possibility of the right access to this being) manifests a being that understands being. It is in view of the showing power of these comportments that Heidegger says that they are constitutive of questioning and of the being of questioner:

Turning the gaze, understanding and grasping of, choosing and access to, are constitutive comportments of questioning and are thus themselves modes of being of a certain being that we questioners ourselves always are. ${ }^{26}$

Taking cognizance of these comportments, and bearing in mind that each manifests understanding of being, we realize that questioning is not an adden$d u m$ to understanding of being but inheres in this understanding. We also 
realize that the access to the preeminent and exemplary being is to be found in this inherence. To grasp this access, we must focus on the inherence of questioning in understanding of being.

We must explicitly deal with this inherence, because the being to be interrogated is a being that asks the question of being and in so doing reveals that question of being inheres in understanding of being. What then is entailed in this inherence? By attending to this issue we shall arrive at a specific notion of questioning, which will lead us to preeminent exemplary being that Heidegger calls Dasein. Doing so we shall take a significant step toward grasping the question of being as a question to which being is retro- or forward related and within which being reverberates and is the foremost hermeneutic pre-condition for interpreting Heidegger's thought.

The questioning that takes the shape of the question of being has at least three distinctions: it is not extraneous to understanding of being; it is determined and affected by being, and it is a specific possibility. By attending to these three distinctions, we shall see clearly that questioning is the key for grasping the preeminence of the exemplary being. We shall then be in a position to see that since being is retro- or forward related to question of being, being is also retro- or forward related to preeminent exemplary being that Heidegger identifies at the end as Dasein.

The conjoined appearing of questioning and understanding of being brings light to questioning as well as to understanding of being. This conjoined appearing has an unmistakable impact on understanding of being insofar as questioning brings this understanding to the fore. This is to say that understanding of being is already at work in the pre-philosophical domain, and unfolds prior to questioning, but we take cognizance of this understanding only after it becomes phenomenologically observable by virtue of questioning. This means that understanding of being as an ongoing and continually unfolding understanding becomes philosophically explicit and comes to the fore through questioning.

When we look at the conjoined appearing of questioning and understanding of being, beside noticing that prior to questioning, understanding of being already operates and unfolds, we also notice that question of being is determined by what is asked about in this question, i.e., by being. We grasp this determinedness of questioning by being when we carefully observe what transpires in the very asking of the question of being:

Asking this question as a mode of being of a being, is itself essentially determined by what is asked about, that is by being. ${ }^{27}$

Heidegger makes this determinedness more clear when he speaks of an essential affectedness (wesenhafte Betroffenheit) of questioning by being. Thus he 
indicates clearly that it is being that not only essentially determines this questioning but also affects this questioning as a mode of being of the being to be interrogated. When he says that

The essential affectedness of questioning by what it asks belongs to the ownmost meaning of the question of being. ${ }^{28}$

Heidegger further specifies the determinedness and affectedness of this question by being, respectively determinedness and affectedness of the mode of being of questioner by being. It is in the light of essential determinedness and affectedness of questioning by being that for the first time in the course of the analysis of structure of question of being, Heidegger speaks of being's retroor forward relatedness to, and its reverberation in this question. This relatedness and reverberation distinguish the preeminent exemplary being.

Heidegger puts this relatedness and reverberation in the forefront of discussion, and thus brings an unsurpassable light to the decisive moment in the constitution of the preeminent and exemplary being when he underscores that there is

[...] a remarkable «retro- or forward relatedness» of what is asked about (being) to questioning as a mode of being of a being. ${ }^{29}$

We must carefully attend to the implications that being's retro- or forward relatedness has for delimiting the preeminent exemplary being, because being's retro- or forward relatedness to questioning is also a relatedness to the being of questioner - to the preeminent exemplary being. By stressing being's retro- or forward relatedness to the question of being Heidegger makes it unmistakably clear that to delimit the preeminent exemplary being as questioner, we must be guided by this relatedness since this relatedness is manifest in the being of questioner. Thus it becomes necessary that we bring to the fore the being of questioner, which Heidegger works out as the existence (Existenz) of Dasein.

\section{Existence, the «Site» of Retro- or Forward Relatedness of Being}

If we are to come to grips with the being of questioner as a preeminent and exemplary being without losing sight of being's retro- or forward relatedness to questioning, then we must take a more penetrating look at questioning, since questioning is the focal point of that relatedness. By taking this direction we shall see that questioning shows that being's retro- or forward relatedness is manifest in the being of questioner — in the being of preeminent exemplary being - which Heidegger further determines as the existence of 
Dasein. And this is another way of saying that existence is the «site» that manifests being's retro- or forward relatedness to, and its reverberation in the question of being.

Detection and articulation of being's retro- or forward relatedness to question of being is the crowning achievement of Heidegger's analysis of the structure of this question. By unraveling this relatedness, Heidegger points to the direction that we have to take if we want to grasp existence of Dasein, understand fundamental-ontological thinking, and mutatis mutandis being-historical thinking. When Heidegger in Being and Time shows that it is via questioning that we can see the difference between being and beings (ontological difference); when via questioning he shows that being is that in view of which a being is understood, and when he works out the being of questioner as existence - he accomplishes all of this because his analysis of structure of question of being reveals that being is retro- or forward related to questioning. Likewise, when in Contributions to Philosophy Heidegger states "Whenever a being is, being must sway. But how does be-ing sway?» 30 and responds to this question by alluding to "the essential swaying of be-ing itself. [i.e.,] enowning (Ereignis)», 31 he asks this question and responds to it because through the analysis of the question of being in Being and Time he detects and articulates being's retro- or forward relatedness as what is manifest in existence, i.e., the being of questioner.

Given then the central significance of questioning for grasping existence and both pathways of Heidegger's thinking, it becomes clear that we must undertake a renewed analysis of questioning. Following this analysis we shall see that existence is the «site» which manifests being's retro- or forward relatedness. A renewed analysis of questioning shows questioning to be as an existential possibility. We understand this possibility by considering two deciding determinations - one which concerns the preeminent and exemplary being, the other which concerns questioning. With the first determination Heidegger delimits preeminent exemplary being as Dasein in that he explicitly hones in on questioning as a possibility for this being to be:

The being that we ourselves always are and among other things has the possibility to be the asking of question, we grasp terminologically as Dasein. ${ }^{32}$

With the second determination Heidegger locates this possibility in the being of questioner, i.e., in existence and finds that this possibility is an existential possibility.

In order to grasp determination of the preeminent exemplary being as Dasein, we have to focus solely on questioning as a possibility. What kind of possibility is this possibility of questioning? It is a possibility that preeminent exemplary being has to be, i.e., the possibility of asking the question of being 
which Heidegger captures with the words die Seinsmöglichkeit des Fragens. ${ }^{33}$ Preeminent exemplary being called Dasein has the possibility to be the asking of the question of being, which is another way of saying that this being has to be this possibility.

But this possibility is an existential possibility insofar as

[...] possibility as an existential is the most original and the ultimate positive ontological determination of Dasein $[\ldots]^{34}$

Now when we look at these two determinations, we realize that each in its own way presupposes the existence of Dasein, since to be the possibility of asking the question of being is to be as an existential possibility - to be in the way of existing.

We obtain a clear understanding of possibility as an existential possibility when we differentiate it from traditional concept of possibility. Once this is accomplished, we shall see that being's retro- or forward relatedness to questioning is also a relatedness to the existence of Dasein.

With possibility Heidegger means, on the one hand having the possibility of asking the question of being, and on the other, to be the mode of being which is the asking of this question. This possibility refers to the domain of having insofar as, except for Dasein, no other being has the possibility to be the mode of asking the question of being. Because Dasein has the possibility to be the mode of being that is called asking the question of being Dasein exists as this possibility. This possibility remains what it is whether or not question of being is asked in actuality, which is another way of saying that this possibility cannot be grasped in terms of actuality - it should be grasped in terms of existence.

To further distinguish this possibility from the possibility that stands in opposition to actuality it should be pointed out that Dasein always already is this possibility and Dasein always already is this mode as questioning, since this possibility is not what Dasein in actuality is «not-yet» but later can or may become. To put it succinctly, this possibility is radically different from the possibility that is referentially dependent upon actuality as its modality. The possibility that Dasein is, is not the same possibility that is the modal category of an extant actuality:

Possibility as the modal category of extantness means what is not yet actual and what is never necessary, and which delineates the merely possible and is ontologically inferior to actuality and necessity. ${ }^{35}$

It is in view of this possibility that Dasein proves to be a being that has to be the existential possibility of asking the question of being. We must take 
this possibility as our guide in order to explicitly address what Heidegger calls existence.

To be prepared for undertaking this task, we want to take a quick look at the stretch of the way we have left behind. We proceeded from being as that in view of which a being is understood in its being; we found that the being to be interrogated is situated in understanding of being which led us to the conjoined appearing of questioning and this understanding. It was necessary to focus on questioning which was distinguished by its determinedness, and affectedness by being and to which being proved to be retro- or forward related. It was at this juncture that questioning proved to be that to which being is retro-or forward related. Via questioning we found that being is also retro- or forward related to questioner, to Dasein whose being Heidegger calls existence. Our effort to determine existence departs from the possibility that Dasein has to be.

We have to obtain a clear understanding of this possibility since we want to understand the manner in which being is retro-or forward related to the being of Dasein, i.e., to existence. To this end, we turn to a passage in Sein und Zeit, which presents a concise and foundational account of existence. The passage reads:

Dasein is a being that does not merely occur among other beings. Rather, it is ontically distinguished insofar as this being in its being is concerned with this being itself. In that case then constitution of the being of Dasein is such that having a relationship of being to this being belongs to this constitution. And this in turn means, that in some way and with some explicitness, Dasein understands itself in its being. It is peculiar to this being that its being is disclosed to itself with (mit) and through (durch) this being. ${ }^{36}$

By carefully interpreting each sentence in this passage, we shall see what is existence all about. This will enable us to see that being's retro- or forward relatedness to questioning is also a retro- or forward relatedness to existence.

With the first sentence, Heidegger differentiates Dasein from other beings, and thus begins to introduce the reader to existence of Dasein. The key for understanding this differentiation lies in what Dasein might be said to share with other beings: it too occurs among beings. If, from a certain point of view, we can say that Dasein occurs among beings like trees, birds, stars, etc., then we must hasten to add that this occurring does not say everything there is to say about Dasein. For, beside occurring among beings Dasein also manifests something that no other being manifests. It is with the second sentence that Heidegger tells us what this something is.

The justification for saying that in addition to merely occurring among beings Dasein also manifests something else is this. When we look at Dasein,

36. GA2/ 16. Regarding this passage, cf., F.-W. vOn HERRMANn (1987), Hermeneutische Phänomenologie des Daseins: Eine Erläuterung von "Sein und Zeit», vol. 1 (Frankfurt am Main: V. Klostermann), p. 106-109. 
we notice that Dasein distinguishes itself ontically from other beings in that Dasein in its being is concerned with this being itself. In the original German, Heidegger places in italics the word um in es geht um, i. e., "concerned with" because he wants to stress the specific ontological meaning of this word. Dasein's concern with its being is a purely ontological concern and as such it has nothing in common with an ego-centered and ego-oriented concern that occupy theories of morality, psychology, etc. We grasp the specific ontological meaning of this concern by recalling the sense of "to be» which we encountered when we spoke of «to be the possibility of the asking» of the question of being. To be concerned with its being means that Dasein is concerned with a possibility that it has to be. We must grasp the expression "concerned with" in this light, because this concern points to a possibility that is not a modality of actuality. (We should never lose sight of the fact that this possibility is not a modality of actuality, because this modality can never be the possibility which is the asking of the question of being.) We grasp «concerned with» purely ontologically, when we take it in the context of a possibility that Dasein has to be, which we identify as the asking of question of being. Considering that questioning too is such a possibility and recalling that being is retro- or forward related to questioning, we can say that to be concerned with its being, Dasein has to be that possibility to which being is retro- or forward related. With this finding, we have not yet grasped the existence of Dasein but we have taken a major step in its direction. It is with the third sentence that Heidegger brings us closer to the existence of Dasein.

We gain more insight into Dasein's concern with its being when we grasp what Heidegger says in the third sentence and realize that this concern points to a relationship, which unlike theoretical relationalities is constitutive of Dasein's being, because this relationship is shaped as being. That is why Heidegger calls it a relationship of being - a Seinsverhältnis. Looked at closely, this relationship too has to be grasped as the possibility that Dasein has to be, that is the possibility with which we became familiar when we addressed the possibility which is the asking of the question of being. By determining that Dasein's concern with its being is a relationship of being, Heidegger finds that Dasein has to be this relationship, which is another way of saying that this relationship is constitutive of Dasein's being. Put in negative terms, we might say that Dasein cannot afford not to be this relationship. In order for Dasein to be this relationship, Dasein has to enact this relationship. Thus it becomes clear that this relationship is not a matter of theory but a matter of enacting: Dasein has to be this relationship by enacting it. As we attend to other sentences in this passage, we shall see that in the final analysis what is enacted is existence. And to enact existence means enacting a relationship of being as a possibility to be to which being as such is retro- or forward related. Heidegger elucidates this enactment with what he says in the sentences with which he concludes this passage.

With the forth sentence Heidegger draws an important conclusion from Dasein's relationship of being as a possibility that Dasein has to be. In view of 
this relationship, Dasein understands its being «in some way and with some explicitness». To say that Dasein understands its being more or less explicitly is to say that this understanding is never complete - it is ongoing. Moreover, to say that Dasein understands its being more or less explicitly is to say that this understanding does not turn the being of Dasein into an object of reflection. This means that the more or less explicit understanding of Dasein's being does not occur in the realm of reflection. And the reason for this is clear: insofar as this understanding is understanding of what Dasein has to be as a possibility, and because this possibility cannot be objectified as actuality, Dasein's understanding of its being is not accessible to reflection and objectification.

Presenting one of Heidegger's foundational insights, the last sentence in this passage has a guiding significance that extends to question of being, and via this to fundamental-ontological as well as being-historical pathways of his thinking. It reads:

It is peculiar to this being that its being is disclosed to itself with (mit) and through (durch) this being. ${ }^{37}$

We call this sentence foundational because by the use Heidegger makes of the words with and through this sentence paves the way for understanding that being is retro- or forward related to existence of Dasein (not exclusively to questioning) which among other things manifests the enactment of that relatedness. The guiding significance of the words "with», and "through" is such as to elucidates existence and via this Heidegger's fundamental-ontological, and mutatis mutandis his being-historical thinking. Therefore, our attempt to understand that being is retro- or forward related to existence of Dasein - an attempt that is guided by this foundational insight — begins with taking a close look at these two words.

It should be pointed out that when Heidegger says that it is peculiar to Dasein that its being is disclosed to itself with this being, here the word "with" does not imply that disclosedness (Erschlossenheit) comes along with, or that it accompanies Dasein's being. Rather, here this word with should be taken in the sense of «in accordance with». In this sense then when we read that Dasein's being is disclosed to itself "with" this being, we understand this disclosedness as what happens in accordance with Dasein's thrownness into disclosedness of being. This demonstrates that the word "with» is Heidegger's first formal indication of thrownness (Geworfenheit) of Dasein into disclosedness of being.

It should also be pointed out that when Heidegger says that it is peculiar to Dasein that its being is disclosed to itself through this being, the word "through" does not imply that Dasein goes into this disclosedness at one end as it were, and comes out of it at the other end. Rather, this word «through» should be taken in the sense of «by means of.» In this sense then when we read that 
Dasein's being is disclosed to itself «through" this being, we understand this disclosedness as what happens by means of this being. Disclosedness happens by means of this being, because Dasein is the being that projects-open its thrownness into disclosedness of being. This demonstrates that the word «through» is Heidegger's first formal indication of projecting-open or Entwurf.

Having established that "with" formally indicates thrownness into disclosdness of being, and "through" formally indicates projecting-opening of disclosedness of being, we return to our foundational sentence. To say that it is peculiar to Dasein that its being is disclosed to itself with and through this being, is the same as saying that Dasein is a thrown-projecting-open, i.e., a geworfener Entwurf. Dasein is a thrown-projecting-open, because it projects-open the disclosedness of being into which Dasein is thrown. When we look closely at this «thrownness," this "projecting-open» — at this "with», and "through» — we realize that with this foundational sentence Heidegger puts forth a comportment. For to be disclosed in its being Dasein enacts a comportment that involves thrownness and projecting, i.e., is a thrown-projecting-open. It is by exclusively holding this comportment in his regard that Heidegger circumscribes existence:

We call existence the being itself toward which, one way or the other, Dasein can comport itself, and somehow always comports itself. ${ }^{38}$

And this is not a comportment that is wholly new to us. We came across this comportment, albeit without explicitly calling it a comportment, when we spoke of the possibility to be the asking of the question of being; when we addressed being's retro- or forward relatedness to the disclosed possibility of questioning. By addressing the asking of the question of being as a possibility to be, by stressing being's retro- or forward relatedness to questioning, we presupposed the enactment of a comportment, which as thrown projecting-open, is Dasein's way of comporting itself toward its being. This comportment is nothing other than enactment of existence. Now insofar as being is retro- or forward related to questioning and insofar as questioning presupposes the enactment of existence, we have to say that being is also retro- or forward related to existence. We see more clearly being's relatedness to existence when we examine this enactment closely.

As comporting toward the being that Dasein is, existence is distinguished by a transcending, or surpassing insofar as when existence is enacted, (when thrown projecting-open of disclosedness of being comes to pass) Dasein surpasses its own being as well as the beings among whom Dasein is. This means that in each and every instance when Dasein experiences what «is» (be it a chair or a god that is) Dasein surpasses its own being as well as beings among whom Dasein is, since Dasein projects-open the disclosedness of being into 
which Dasein is thrown. It is in full consideration of this surpassing that Heidegger says of being that it is nothing other than transcendence:

Being and structure of being surpass each and every being and every possible existent (seiende) determination of a being. Being is transcendence pure and simple. ${ }^{39}$

The comportment that is called existence is the enactment of a surpassing, i.e., enactment of transcendence or being. This has significant consequences for grasping being's retro- or forward relatedness to existence.

When we speak of being's retro- or forward relatedness to existence, we should keep in mind that it is as transcendence that being is retro- or forward related to existence. Being is retro- or forward related to existence - reverberates therein - insofar as enactment of existence is what sustains the comportment called questioning to which as we have seen being is retro- or forward related. To expound on this a bit further, we can say that since enactment of existence is enactment of transcendence, and because being is transcendence pure and simple, and because being is retro- or forward related to questioning, we have to say that being is also retro- or forward related to existence insofar as existence is the being of Dasein as questioner. Thus we establish that existence is the «site» to which being is retro- or forward related.

It is in view of the surpassing or transcending that occurs as existence, as well as in consideration of determination of being as transcendence pure and simple that Heidegger rejects as irrelevant any attempt that wants to reduce transcendence and transcendental in fundamental ontology to be Kant's and Husserl's transcendental thinking. ${ }^{40}$ For, neither of the these two thinker has access to existence of Dasein, that is the "site» wherein being's retro- or forward relatedness is manifest as transcendence.

\section{The Yields of the Question of Being}

Guided by a concerted effort to bring to light the structure of the question of being as well as the questioning that unravels this structure, we are now in a position to gather together the outcome of this effort and to address what this journey in the domain of the question of being yields. We address this yield directly when we point to a circle that runs from being's retro- or forward relat-

39. GA 2/ 51.

40. On this point see M. Heidegger, "Zum Einblick in die Notwendigkeit der Kehre», in Vom Rätsel des Begriffs: Festschrift für F.W. von Herrmann, ed. Paola-Ludovika Coriando (1999), Berlin: Duncker \& Humboldt, p. 1-3. One of the many flaws of T. Kisiel's The Genesis of Heidegger's "Being and Time», is precisely the failure to grasp transcendence and transcendental in terms of the enactment of existence. Cf., ibid, p. $313 \mathrm{ff}$. When Kisiel speaks of Heidegger's renewed interest in Kant and assumes that transcendence is an extension of Kant's transcendental thinking, he (Kisiel) betrays a fundamental lack of understanding existence according to fundamental ontology. 
edness to questioning, and from questioning back to being's retro- or forward relatedness. We address this yield directly when we allude to a circle that runs from the question of being to existence and to fundamental ontology and from existence and fundamental ontology back to question of being. It goes without saying then that this retro- or forward relatedness sustains Being and Time in which Heidegger unfolds the pathway of transcendental-horizonal thinking. It also goes without saying that this retro- or forward relatedness sustains Contributions to Philosophy in which Heidegger unfolds the pathway of beinghistorical thinking. What brings us to this conclusion is the realization that questioning succeeds in unraveling the structure of the question of being, because questioning is that to which being is retro- or forward related. This relatedness foreshadows what must be called belongingness of this question to, and its empowerment by being, which is one of the many insights that we gain from a close reading of Heidegger's Contributions to Philosophy.

The retro- or forward relatedness of being to the question of being brings an unsurpassable light to Dasein and shows that it is being as such that shapes the unfolding of the entire course of fundamental ontology. If retro- or forward relatedness of being to the question of being brings light to Dasein and to fundamental ontology, then this ontology must be grasped in the light of retro- or forward relatedness of being to Dasein via the question of being. And this shows how irrelevant it is to speak of a "Heidegger I", "Heidegger II», a "Dasein-oriented versus a being-oriented ${ }^{41}$ phase in Heidegger's thinking. Given this retro- or forward relatedness of being to questioning, we have to say that question of being is a question that directly and unmistakably is under the sway of being. Which is another way of saying that this question is neither an ethereal question nor delivers an alternative ontological model, nor conceives being in traditional terms, nor is an activity privileged by the human subject but is a question that comes from being because being is retro- or forward related to, and reverberates in this question.

41. See J.J. Kockelmans (1985), Heidegger on Art and Art Work, Dordrecht: Martinus Nijhoff, p. 76. 